\title{
Effects of Season and Stage of Rotation Cycle on Hydrologic Condition of Rangeland Under Intensive Rotation Grazing
}

\author{
S.D. WARREN, W.H. BLACKBURN, AND C.A. TAYLOR, JR.
}

Abstract

Infiltration rate and sediment production were measured over a 2-year period on an intensive rotationally grazed pasture. Measurements were taken prior to the movement of livestock onto the pasture, soon after their removal, and approximately midway through the subsequent rest period of each rotation through the system. Midgrass-dominated interspaces were characterized by significantly higher infiltration rates and lower sediment production than shortgrass-dominated interspaces. Infiltration rate declined and sediment production increased following the short-term intense grazing periods inherent in the rotational system. The detrimental effect was significant during periods of drought or winter dormancy, but not during periods of active growth. Soll characteristics relating to higher hydrolozic condition were significantly more stable during the growing season, providing greater resistance to and resilience from the damaging impact of livestock activity.

Mismanagement of domestic livestock, especially through excessive stocking rates, has caused severe degradation of many of the world's rangelands (Bentley 1898, Box 1967, Dregne 1978). Moderate stocking rates which are designed to utilize approximately half of the current year's forage production are generally accepted as proper grazing management (Stoddard et al. 1975). However, even when "proper" stocking rates are achieved, livestock may selectively overutilize specific areas, certain forage species, or even individual plants. One tool to help prevent such uneven distribution of grazing is the implementation of rotational grazing systems. Additional goals of grazing systems include improvement or maintenance of the forage resource and increased animal production.

Over the last decade there has been a renewed interest in intensive rotation grazing, a concept which originated prior to the 19 th century (Voisin 1959). Modern proponents of the system predict that, in addition to improved plant and animal production, the intense livestock activity associated with short-term, high stocking density will increase infiltration of rainfall into the soil and reduce erosion, even at stocking rates which double or triple the conventional moderate rates (Goodloe 1969, Savory 1978, Savory and Parsons 1980). Most scientific research with rotational grazing systems has shown that heavy stocking rates decrease infiltration rate and increase sediment production, regardless of the system used (Blackburn 1984; Gamougoun et al. 1984; McCalla et al. 1984a, 1984b; Pearson et al. 1975; Pluhar 1984; Smith 1980; Thurow 1985; Warren et al. 1986c; Weltz 1983). Even at moderate stocking rates, rotational grazing systems have no consistently significant hydrologic advantages over continuous grazing (Blackburn 1984; Blackburn et al. 1980; Knight 1980; Mbakaya 1985; McGinty et al. 1979; Skovlin et al. 1976; Wood 1980; Wood and Blackburn 1981a, 1981b; Wood et al. 1978).

Although the overall hydrologic impact has been evaluated for many rotational grazing systems, little is understood about the

\footnotetext{
Authors are presently environmental research scientist, USA-CERL, Environmental Division, P.O. Box 4005, Champaign, Ill. 61820, professor of watershed management, Department of Range Science, Texas A\&M University, College Station 77843, and superintendent, Texas Agricultural Experiment Station, Sonora 76950. At the time of this research the senior author was graduate research assistant at Texas A\&M University.

This study was a cooperative project between U.S. Department of Agriculture and Texas Agricultural Experiment Station. Financial support of the Soil Conservation Service RCA Special Study and a Science/Education Grant is acknowledged. Published with approval of the Director, Texas Agricultural Experiment Station as TA-20993.

Manuscript accepted 10 April 1986.
}

mode of action by which the watershed is impacted. The purpose of this investigation was to test the hypothesis of hydrologic improvement under intensive rotation grazing in relation to stage of the rotation cycle and seasonal variability.

\section{Study Area}

Field research was conducted at the Texas Agricultural Research Station located on the Edwards Plateau near Sonora, Texas. In the fall of 1982, a 376-ha, 14-pasture intensive rotation grazing system was put into operation at the Station. Pastures ranged in size from 8 to $32 \mathrm{ha}$. The system was stocked with a single herd composed of a 1.63:1:1 ratio of cattle, sheep, and goats at a stocking rate of 8.1 ha/ $\mathrm{AU}$, which is the recommended moderate rate. The number of days of grazing per pasture per rotation cycle was dependent upon the condition of the forage resource within each pasture. During the spring and summer, the average rotation cycle was 56 days but slowed to 74 days during the winter dormant season.

A 32-ha pasture was used for this study. The pasture was in better condition than most others and was grazed at a heavier rate accordingly. During a typical 56-day rotational cycle, the pasture was grazed for $\mathbf{8}$ days, so that it was representative of a 7-pasture intensive rotation grazing system stocked at $4.8 \mathrm{ha} / \mathrm{AU}$ or $1.7 \mathrm{x}$ the recommended moderate rate. Stocking density while livestock were on the pasture was $0.68 \mathrm{ha} / \mathrm{AU}$.

The physiognomy of the pasture was characterized by dense, scattered live oak (Quercus virginiana Mill.) mottes with grass interspaces. The midgrass component of the grass interspaces was dominated by sideoats grama (Bouteloua curtipendula (Michx.)) and Wright's threeawn (Aristida wrightii Nash). Other important midgrass included fall witchgrass (Leptoloma cognatum (Schult.) Chase), Texas wintergrass (Stipa leucotricha Trin. \& Rupr.), and silver bluestem (Bothriochloa saccharoides (Swartz) Rydb.). The shortgrass interspaces were predominantly common curly mesquite (Hilaria belangeri (Steud.) Nash). Honey mesquite (Prosopis glandulosa Torr.) and ashe juniper (Juniperus ashei Buchholz), 2 woody species, were scattered through the grass interspaces in a savannah-like fashion. Prickly pear (Opuntia spp. Mill.) was also abundant.

Study sites were located on Kavett silty clay soils with slopes $<3 \%$ and a depth of $250-500 \mathrm{~mm}$ overlying a fractured caliche layer and limestone substratum. The soils were of the clayeyskeletal, montmorillonitic, thermic family of Lithic Haplustolls, characterized by high shrink-swell capacity and high organic matter content. When undisturbed, they were well aggregated and had high rainfall infiltration capacity.

Therefore, dormant season, for purposes of this paper, refers to any extended period of vegetation dormancy, whether induced by cooler temperatures and shorter day length during the winter, or by extended drought, regardless of the time of year.

\section{Methods}

Beginning in the fall of 1982 when the intensive rotation grazing system was installed, and continuing until the fall of 1984, pastures were sampled immediately prior to the entry of livestock, soon after their removal, and approximately midway through the subsequent rest period of each rotation through the system. Two rotation cycles were omitted due to freezing temperatures which prevented rainfall simulation. Sixteen plots were sampled on each 
sample date at sites which were randomly located within the pasture. Half of the plots represented midgrass interspaces and half represented shortgrass interspaces.

A mobile, drip-type rainfall simulator (Blackburn et al. 1974) was used to determine infiltration rate and sediment production on variable area runoff plots. Plot size averaged approximately 0.4 $\mathrm{m}^{2}$. In order to reduce variability attributable to antecedent soil water content, the plots were pre-wet by applying 105 area $\mathrm{mm}$ of water at a rate of $79 \mathrm{~mm} \mathrm{~h}^{-1}$ from a mist type nozzle located under a plastic cone $0.6 \mathrm{~m}$ above the soil. The plots were then covered with plastic tarps to prevent evaporation, and gravitational water was allowed to drain. After approximately 24 hours, when the soil had drained to near field capacity, simulated rainfall was applied at a rate of $203 \mathrm{~mm} \mathrm{~h}^{-1}$ for 30 minutes. The simulated raindrops were $2.5 \mathrm{~mm}$ in diameter. Drops falling $2.1 \mathrm{~m}$ reached $5.25 \mathrm{~m} / \mathrm{sec}$ or $71 \%$ of the terminal velocity achieved by raindrops in an unlimited fall (Laws 1941). This application rate simulated a storm with a return period of about 120 years and was necessary to insure runoff from all plots. Runoff from each plot was regularly pumped into tared containers. At five minute intervals the runoff was weighed and mean infiltration rate $\left(\mathrm{mm} \mathrm{h}^{-1}\right)$ was calculated by determining the difference between applied rainfall and the quantity of water running off the plot. At the end of each simulated rainfall event, runoff from the plot was thoroughly mixed and a 1-liter subsample was collected. The subsample was filtered through a tared Whatman \#1 filter. Sediment remaining on the filter was oven-dried, weighed and converted to sediment production $\left(\mathrm{kg} \mathrm{ha}^{-1}\right)$ based on the area and total runoff from each plot.

Immediately prior to each simulated rainfall event, soil bulk density and soil moisture content at a depth of $0-50 \mathrm{~mm}$ were determined adjacent to each runoff plot by the core method (Blake 1965) and gravimetric method (Roundy et al. 1983), respectively. Soil surface microrelief within each plot was measured with a 10-pin relief meter similar to the one described by Kincaid and Williams (1966). Following simulated rainfall, a composite surface soil sample was taken to a depth of $30 \mathrm{~mm}$ from within the plot and was used for analyses of soil organic matter content by the Walkley-Black method (Nelson and Sommers 1982) and aggregate stability by the wet-sieved method (Kemper 1965).

Percent aerial cover of midgrasses, shortgrasses, forbs, litter, rock, and bare ground was determined by ocular estimate for each runoff plot. Midgrass, shortgrass, and forb cover were combined to produce a single vegetative cover estimate. Litter cover was added to the vegetative cover total to produce a total organic cover estimate. Following rainfall simulation, grasses and forbs were clipped to a $10-\mathrm{mm}$ stubble height and litter was hand collected from each plot. These samples were oven-dried and weighed. Grass and forb weights were combined to produce a standing crop value, and litter was added to calculate total above-ground herbaceous biomass.

Biomass variables and soil microrelief were highly skewed. $\log _{10}$ transformations were performed to meet assumptions of normality. Analysis of variance based on a $3 \times 2 \times 2$ factorial design was used to determine if significant differences existed for dependent variables between stages of the rotation cycle (pre-graze, postgraze, mid-rest), seasons (growing, dormant), and grass types (midgrass, shortgrass). The error term in the analysis of variance consisted of the nested variation of the randomized sites within the factorial treatments (Snedecor and Cochran 1971). If differences were present, Duncan's multiple comparison test was used to separate the means (Steel and Torrie 1980). Simple correlation was computed for all combinations of dependent and independent variables. A significance level of $95 \%$ was used throughout.

\section{Results and Discussion}

The average growing season at the Station is 240 days and extends from March through October. Precipitation during 1983 (501 $\mathrm{mm})$ was considerably below the long-term (1918-1984) aver-

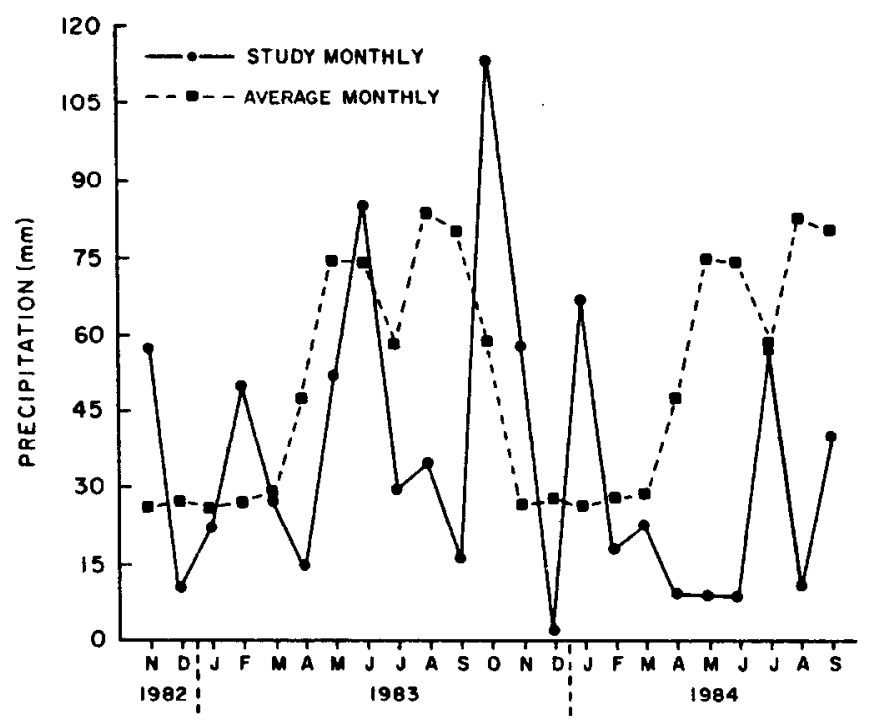

Fig. 1. Long-term average monthly precipitation (1918-1984)and monthly precipitation during the study, near Sonora, Texas.

age of $609 \mathrm{~mm}$ (Fig. 1). Drought conditions were even more severe the following year, with only $406 \mathrm{~mm}$ precipitation, from $10 \mathrm{Janu}$ ary to 25 July 1984 there were no significant rainfall events $(>10$ $\mathrm{mm}$ ). This resulted in a drought-induced extension of the dormant season well into the summer.

Infiltration rate was significantly greater (162 vs. $121 \mathrm{~mm} \mathrm{~h}^{-1}$ ) and sediment production significantly less (937 vs. $1,559 \mathrm{~kg} \mathrm{ha}^{-1}$ ) from plots located in midgrass interspaces than from plots representing shortgrass interspaces. Similar differences in hydrologic response due to grass type have been noted by Knight (1980); McCalla et al. 1984a, 1984b; Pluhar (1984); Thurow (1985); and Wood and Blackburn 1981a, 1981b. There was no significant interaction between grass type and other treatment factors. Therefore, grass types are combined for discussion of seasonal variability and stage of rotation cycle.

\section{Seasonal Variability}

Mean infiltration rate was significantly higher and sediment production was significantly lower during the growing season than during priods of dormancy (Fig. 2). Knight (1980), McCalla et al. (1984a), and Thurow (1985), also working at the Sonora station, reported similar seasonal variability for infiltration rate. Standing crop was the only vegetation or cover variable which varied significantly between seasons; it was greatest during the growing season (Table 1).

Most soil-related variables were significantly different between seasons (Table 1). Soil aggregate stability and soil organic matter were significantly higher and soil bulk density was significantly lower during the growing season, creating a more stable soil hydrologic condition. Soil aggregate stability and soil organic matter are highly autocorrelated by virtue of the fact that organic matter is a principal constituent in the binding of individual soil particles into soil aggregates. Soil organic matter content, in turn, is largely dependent on microbial decomposition of litter and humus. Soil microbes are most active during the growing season when soil moisture and soil temperature are favorable and litter is abundant. However, microbial activity may be limited by very high temperatures and low soil moisture conditions. During the summer drought of 1984, soil temperatures at a depth of $50 \mathrm{~mm}$ reached diurnal peaks approaching $37^{\circ} \mathrm{C}$ while soil moisture at that depth dropped as low as $2-3 \%$ on a dry weight basis. These conditions may have limited microbial activity and probably contributed to 

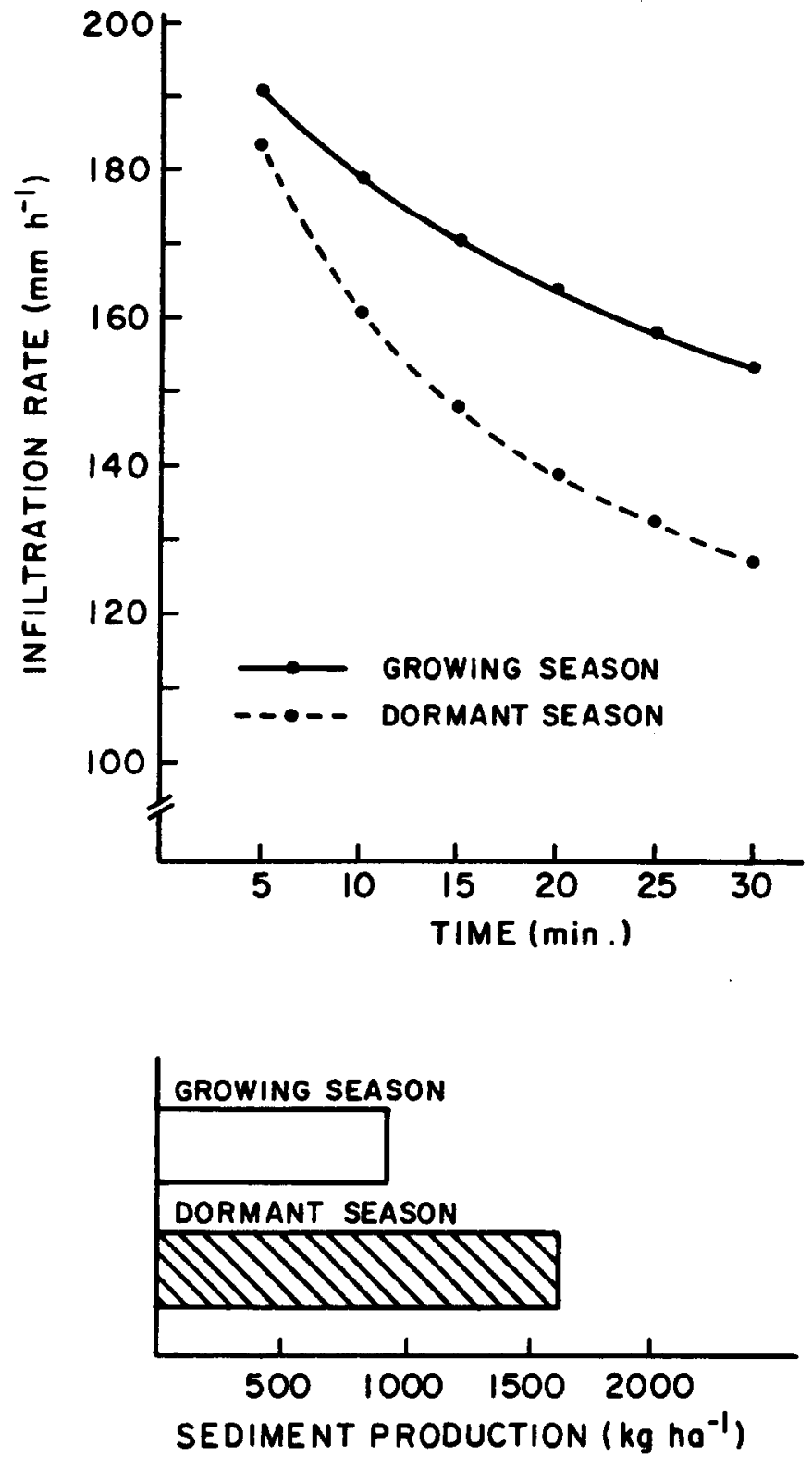

Fig. 2. Mean infiltration rate after 30 minutes and sediment production during the growing and dormant seasons near Sonora, Texas. All means for infiltration rate at the same time interval and for sediment production are significantly different $(\mathrm{P} \leq 05)$.

the lower soil organic matter content and aggregate stability during the dormant season.

The degree of aggregation of soil particles is also positively related to soil bulk density. Porosity of the soil is generally enhanced and soil bulk density reduced as the degree of aggregation increases. Soil porosity during the growing season is also increased by the disruptive action of plant roots. In addition, most of the annual precipitation at the Sonora station falls during the growing season (Fig. 1). The shrinking and swelling of the predominant montmorillonitic clay soils, in response to wetting and drying, lightens the soil and decreases bulk density.

Vegetation variables were significantly correlated with infiltration rate and sediment production during the growing season and during periods of dormancy (Table 2). Grass and litter may intercept a significant portion of incident precipitation (Burgy and Pomeroy 1958, Corbett and Crouse 1968, McMillan and Burgy $1960)$ and thus reduce the impact of falling raindrops. Raindrops
Table 1. Mean vegetation and soil variables during the growing and dormant seasons, near Sonora, Texas.

\begin{tabular}{|c|c|c|}
\hline Variable & Growing season & Dormant scason \\
\hline Bare ground $(\%)$ & $28.3 a$ & $30.3 a$ \\
\hline Litter cover $(\%)$ & $20.5 \mathrm{a}$ & $20.9 a$ \\
\hline Vegetation cover $(\%)$ & $48.6 a$ & $46.5 \mathrm{a}$ \\
\hline Total organic cover $(\%)$ & $69.1 \mathrm{a}$ & $67.4 \mathrm{a}$ \\
\hline Standing crop (kg ha ${ }^{-1}$ ) & $2311.5 \mathrm{a}$ & $1967.7 b$ \\
\hline Litter accumulation $\left(\mathrm{kg} \mathrm{ha}^{-1}\right)$ & $1242.6 \mathrm{a}$ & $1205.5 \mathrm{a}$ \\
\hline \multicolumn{3}{|l|}{ Total above ground herbaceous } \\
\hline biomass $\left(\mathrm{kg} \mathrm{ha}^{-1}\right)$ & $3548.9 \mathrm{a}$ & $3157.1 \mathrm{~b}$ \\
\hline Microrelief (unitless) & $1.15 a$ & $1.11 \mathrm{a}$ \\
\hline Soil bulk density $\left(\mathrm{Mg} \mathrm{m}^{3}\right)$ & $0.77 \mathrm{a}$ & $0.80 \mathrm{~b}$ \\
\hline Soil aggregate stability (\%) & $76.8 \mathrm{a}$ & $62.2 b$ \\
\hline Soil organic matter content $(\%)$ & $6.3 a$ & $5.8 b$ \\
\hline
\end{tabular}

'Means followed by the same letter within a row are not significantly different $(P \leq .05)$.

Table 2. Simple correlation coefficients of vegetation and soil variables correlated with mean infiltration rate after $\mathbf{3 0}$ minutes and sediment production during the growing and dormant seasons, near Sonora, Texas.'

\begin{tabular}{|c|c|c|c|c|}
\hline \multirow[b]{2}{*}{ Independent variables } & \multicolumn{2}{|c|}{ Infiltration rate } & \multicolumn{2}{|c|}{ Sediment production } \\
\hline & $\begin{array}{c}\text { Growing } \\
\text { season }\end{array}$ & $\begin{array}{c}\text { Dormant } \\
\text { season }\end{array}$ & $\begin{array}{l}\text { Growing } \\
\text { season }\end{array}$ & $\begin{array}{c}\text { Dormant } \\
\text { season }\end{array}$ \\
\hline Bare ground & -.56 & -.56 & .53 & .46 \\
\hline Litter cover & .28 & .26 & $-.10 \mathrm{NS}$ & $-.09 \mathrm{NS}$ \\
\hline Vegetation cover & .37 & .42 & -.48 & -.44 \\
\hline Total organic cover & .54 & .57 & -.52 & -.45 \\
\hline Litter accumulation & .41 & .40 & -.22 & -.19 \\
\hline Standing crop & .54 & .47 & -.39 & -.36 \\
\hline Total above ground & & & & \\
\hline herbaceous biomass & .61 & .58 & -.41 & -.36 \\
\hline Microrelief & .45 & .40 & -.30 & -.19 \\
\hline Soil bulk density & -.17 & -.36 & $.04 \mathrm{NS}$ & .14 \\
\hline Soil aggregate stability & .14 & .44 & -.42 & -.32 \\
\hline Soil organic matter content & .13 & .26 & -.27 & -.17 \\
\hline
\end{tabular}

'Correlation coefficients followed by NS are not significant $(P \leq .05)$.

impinging directly on a bare soil surface may dislodge soil particles which may eventually clog soil pores or may be carried away by overland flow (Osborn 1954). Depending on plant morphology, much of the intercepted rainfall may be channeled to the base of the plant (Glover et al. 1962, Gwynne 1966) where plant roots and accumulated litter create a more porous soil characterized by high infiltration rates (Blackburn 1975, Ndawula-Senyimba et al. 1971, Wood and Blackburn 1981a).

Soil variables were also significantly correlated with soil hydrologic response (Table 2). Soil surface microrelief which results from small natural depressions, plant bases, and litter may slow overland flow, increase infiltration rate, and cause deposition of suspended soil particles. However, infiltration rates in depressions caused by cattle tracks may be severely reduced due to compaction (Kako and Toyoda 1981). Soil bulk density was more closely related to infiltration rate than to sediment production. In addition, the relationship was stronger during the dormant season than during periods of growth. Soil aggregate stability and soil organic matter content were also more strongly correlated with infiltration rate during the dormant season. However, these latter variables were more closely tied to sediment production during the growing season.

\section{Stages of Rotation Cycle}

Fluctuations between pre-graze and post-graze hydrologic condition were much more pronounced during dormant periods, regardless of the factors inducing the dormancy (Fig. 3). Overall, 


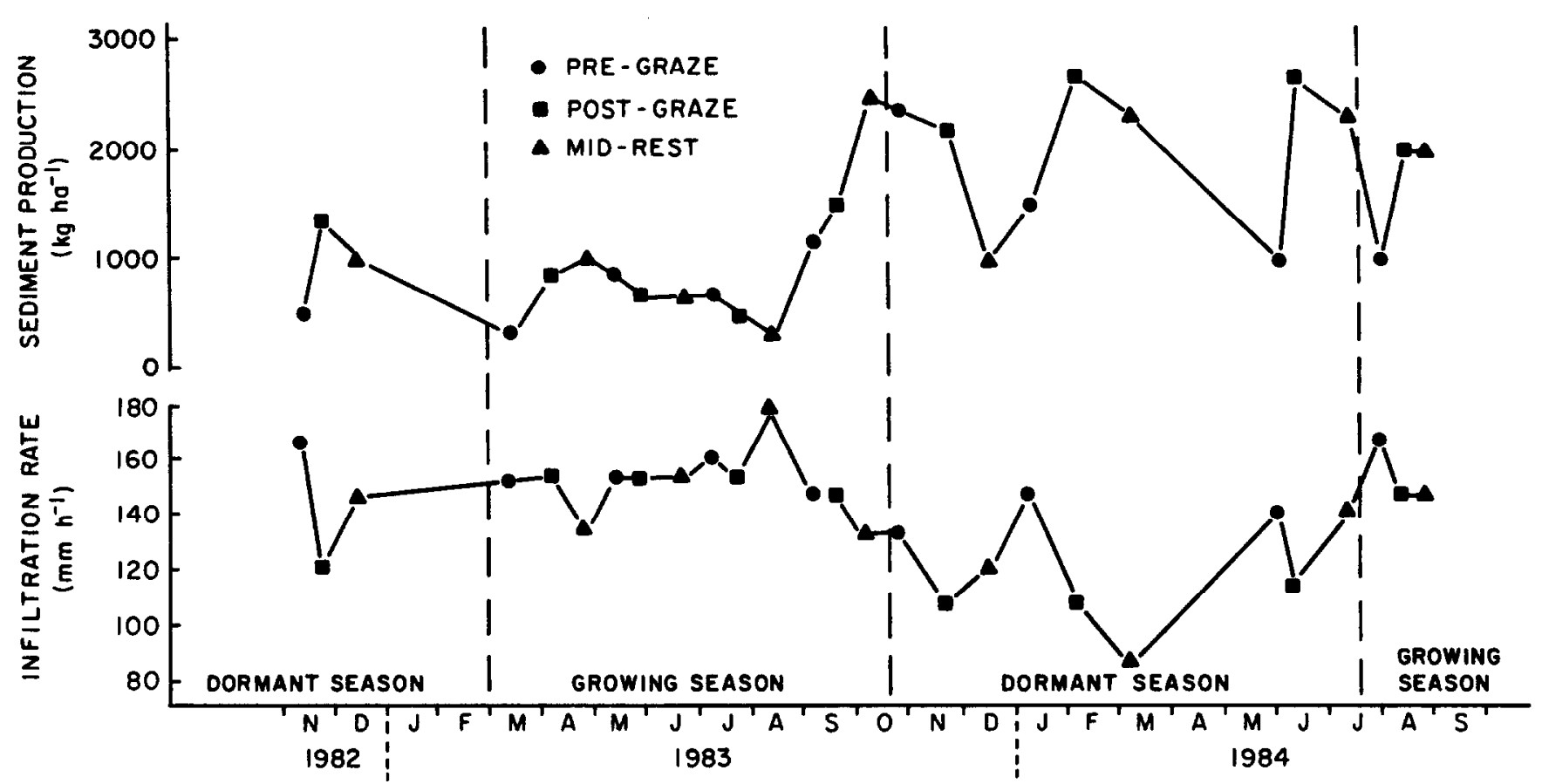

Fig. 3. Mean infiltration rate after 30 minutes and sediment production as related to stage of rotation cycle and season near Sonora, Texas. Dormant season includes winter dormancy and drought-induced dormancy.

during the growing season, mean terminal infiltration rate was somewhat higher before the movement of livestock onto the pasture than immediately after their removal, but the difference was not statistically significant (Table 3). During the dormant season,

Table 3. Mean infiltration rate after 30 minutes and sediment production at different stages of the short-duration grazing rotation cycle during the growing and dormant seasons near Sonora, Texas. ${ }^{1}$

\begin{tabular}{lccccc}
\hline \hline & \multicolumn{2}{c}{$\begin{array}{c}\text { Infiltration rate } \\
(\mathrm{mm} \mathrm{h-1})\end{array}$} & & \multicolumn{2}{c}{$\begin{array}{c}\text { Sediment production } \\
(\mathrm{kg} \text { ha-1) }\end{array}$} \\
\cline { 2 - 3 } \cline { 5 - 6 } $\begin{array}{l}\text { Stage of } \\
\text { rotation cycle }\end{array}$ & $\begin{array}{c}\text { Growing } \\
\text { season }\end{array}$ & $\begin{array}{c}\text { Dormant } \\
\text { season }\end{array}$ & & $\begin{array}{c}\text { Growing } \\
\text { season }\end{array}$ & $\begin{array}{c}\text { Dormant } \\
\text { season }\end{array}$ \\
\hline Pre-Graze & $159 \mathrm{a}$ & $146 \mathrm{a}$ & & $744 \mathrm{a}$ & $1241 \mathrm{a}$ \\
Post-Graze & $153 \mathrm{a}$ & $11 \mathrm{c}$ & & $964 \mathrm{a}$ & $2017 \mathrm{~b}$ \\
Mid-Rest & $150 \mathrm{a}$ & $124 \mathrm{~b}$ & & $1074 \mathrm{a}$ & $1640 \mathrm{ab}$ \\
\hline
\end{tabular}

IMeans followed by the same letter within a column are not significantly different $(P \leq .05)$.

however, the decline in infiltration rate following grazing was significant. Despite the deleterious effect of trampling, some degree of hydrologic recovery did occur during the subsequent rest periods. By midway through the rest period, mean infiltration rate recovered to a level significantly greater than the post-graze condition, but remained significantly lower than the pre-graze condition.

Sediment production responded similarly to infiltration rate but in an inverse fashion (Table 3). The amount of sediment produced during simulated rainfall was greater following grazing than before grazing during both growing and dormant periods. However, as with infiltration rate, the negative impact of high intensity livestock activity was significant only during the dormant periods. Recovery of hydrologic condition in terms of sediment production was evident during the dormant season rest periods. The amount of sediment production declined by midway through the rest period to a level which was not statistically different from either the pre-graze or post-graze condition.

The augmented detrimental impact of intensive livestock activity during the dormant season is probably a reflection of overall lower hydrologic condition of the soil during that part of the year.
Grazing animals not only remove protective biomass through grazing, but their trampling activity may reduce vegetative cover (Bryant et al. 1972, Edmond 1958, Plumb et al. 1984, Quinn and Hervey 1970, Witschi and Michalk 1979), destroy cryptogamic crusts which are essential to hydrologic stability (Brotherson and Rushforth 1983, Loope and Gifford 1972), compact the soil (Chandler 1940, Kako and Toyoda 1981, Knoll and Hopkins 1959, Lull 1959, Van Haveren 1983, Willatt and Pullar 1983, Warren et al. 1986b), decrease soil moisture (Chandler 1940, Edmond 1958, Knoll and Hopkins 1959), decrease soil organic matter content (Chandler 1940), reduce soil aggregate size (Chandler 1940, Warren et al. 1986b), reduce soil aggregate stability (Knoll and Hopkins 1959, Warren et al. 1986b), reduce soil hydraulic conductivity (Willatt and Pullar 1983), and reduce seedling emergence and establishment (Blom 1976, 1977). The ability of a watershed to withstand or recover from livestock impact is undoubtedly related to the hydrologic condition of the watershed at the time of the impact. During the growing season when soil moisture status, soil aggregate stabiity, soil organic matter content, soil bulk density, microbial activity, and above- and below-ground plant growth are near optimum levels, the potential of the soil to withstand livestock impact is high, as is the potential to recover following the removal of livestock. During periods of dormancy, however, the resistance to damage from grazing and for subsequent recovery after grazing is less than during the growing season.

\section{Summary and Conclusions}

Hydrologic response to an intensive rotation grazing system on silty clay soil, in terms of infiltration rate and sediment production, was different during the growing season than during periods of winter or drought-induced dormancy. Infiltration rate was significantly higher and sediment production was significantly lower during the growing season than during periods of dormancy. Greater vegetation standing crop and more stable soil physical characteristics during growth periods contributed to the differences. Mean infiltration rate was consistently lower and mean sediment production was consistently higher following grazing than before. The difference was significant during periods of dormancy but not during the growing season. Unfavorable growing condi- 
tions, reduced activity of soil organisms, and a decline in stability of soil physical properties during periods of dormancy contributed to the inability of the pasture to withstand intense livestock activity or to recover rapidly during the subsequent rest period.

In terms of hydrologic stability, operators of intensive rotation grazing systems should consider lower stocking rates and/or longer rest periods during winter dormancy or during periods of drought. Unfortunately, increasing the length of the rest period is a viable alternative only where the number of pastures is small (Warren et al. 1986a). Where the growing season is short and often unpredictable, as in most semiarid and arid regions, repeated intense trampling may lead to a long-term degradation of the soil resource.

\section{Literature Cited}

Bentley, H.L. 1898. Cattle ranges of the Southwest: A history of exhaustion of pasturage and suggestions for its restoration. USDA Farmers Bull. 72.

Blackburn, W.H. 1975. Factors influencing infiltration and sediment production of semiarid rangelands in Nevada. Water Resources Res. 11:929-937.

Blackburn, W.H. 1984. Impacts of grazing intensity and specialized grazing systems on watershed characteristics and responses, p. 927-983. In: Developing Strategies for Rangeland Management. Nat. Res. Council/ Nat. Acad. Sci. Westview Press, Boulder, Colo.

Blackburn, W.H., R.O. Meeuwig, and C.M. Skau. 1974. A mobile infiltrometer for use on rangeland. J. Range Manage. 27:322-323.

Blackburn, W.H., R.W. Knight, M.K. Wood, and L.B. Merrill. 1980. Watershed parameters as influenced by grazing, p. 552-572. In: Proc. of the Symp. on Watershed Manage. Amer. Soc. Civil Eng., Boise, Ida.

Blake, G.R. 1965. Bulk density, p. 374-390. In:C.A. Black (ed), Methods of Soil Analysis, Part I. Amer. Soc. Agron., Madison, Wis.

Blom, C.W.P.M. 1976. Effects of trampling and soil compaction on the occurrence of some Plantago species in coastal sand dunes. I. Soil compaction, soil moisture and seedling emergence. OEcol. Plant. 11:225-241.

Blom, C.W.P.M. 1977. Effects of trampling and soil compaction on the occurrence of some Plantago species in coastal sand dunes. II. Trampling and seedling estabishment. OEcol. Plant. 12:363-381.

Box, T.W. 1967. Range deterioration in west Texas. Southwestern Historical Quart. 9:37-45.

Brotherson, J.D., and S.R. Rushforth. 1983. Influence of cryptogamic crusts on moisture relationships of soils in Navajo National Monument, Arizona. Great Basin Natur, 43:73-78.

Bryant, H.T., R.E. Blaser, and J.R. Peterson. 1972. Effect of trampling by cattle on bluegrass yield and soil compaction of a Meadowville loam. Agro. J. 64:331-334.

Burgy, R.H., and C.R. Pomeroy. 1958. Interception losses in grassy vegetation. Trans. Amer. Geophys. Union 29:1095-1100.

Chandler, R.F., Jr. 1965. The influence of grazing upon certain soil and climatic conditions in farm woodlands. J. Amer. Soc. Agron. 32:216-230.

Corbett, E.S., and R.P. Crouse. 1968. Rainfall interceptions by annual grass and chaparral...losses compared. USDA Forest Service Res. Pap. PSW-48.

Dregne, H.E. 1978. Desertification: Man's abuse of the land. J. Soil and Water Conserv. 33:11-14.

Edmond, D.B. 1958. The influence of treading on pasture: A preliminary study. N.Z. J. Agr. Res. 1:319-328.

Gamougoun, N.D., R.P. Smith, M.K. Wood, and R.D. Pieper. 1984. Soil, vegetation, and hydrologic responses to grazing management at Fort Stanton, New Mexico. J. Range Manage. 37:538-541.

Glover, P.E., J. Glover, and M.D. Gwynne. 1962. Light rainfall and plant survival in East Africa. II. Dry grassland vegetation. J. Ecol. 50:199-206.

Goodloe, S. 1969. Short-duration grazing in Rhodesia. J. Range Manage. 22:369-373.

Gwynne, M.D. 1966. Plant physiology and the future, p. 59-64. In: W. Davis and C.L. Skidmore (eds), Tropical pastures. Faber and Faber, London.

Kako, Y., and H. Toyoda. 1981. Soil conservation of sloping grassland. V. The infiltration capacity of water on sloping grasslands. (In Japanese). Bull. Nat. Grassl. Res. Inst. 18:127-136.

Kemper, W.D. 1965. Aggregate stability, p. 511-519. In: C.A. Black (ed), Methods of soil analysis, Part 1. Amer. Soc. Agron., Madison, Wis.

Kincaid, D.R., and G. Williams. 1966. Rainfall effects on soil surface characteristics following range improvement treatments. J. Range Manage. 19:346-351. night, R.W. 1980. Hydrologic response of selected grazing systems on the Edwards Plateau. Ph.D. Diss., Texas A\&M Univ., College Station.

Knoll, G., and H.H. Hopkins. 1959. The effects of grazing and trampling upon certain soil properties. Trans. Kansas Acad. Sci. 62:221-231.

Laws, J.O. 1941. Measurements of the fall-velocity of water-drops and raindrops. Trans. Amer. Geophy. Union 22:709-721.

Loope, W.L., and G.F. Gifford. 1972. Influence of soil microfloral crust on select properties of soils under pinyon-juniper in southeastern Utah. J. Soil and Water Conserv. 27:164-167.

Lull, H.W. 1959. Soil compaction on forest and range lands. USDA Misc. Pub. 768.

Mbakaya, D.S. 1985. Grazing systems effects on infiltration rates and sediment production of a bushed grassland, Buchuma, Kenya. M.S. Thesis, Texas A\&M Univ., College Station.

MeCalla, G.R., W.H. Blackburn, and L.B. Merrill. 1984a. Effects of livestock grazing on infiltration rates, Edwards Plateau of Texas. J. Range Manage. 37:265-269.

McCalla, G.R., W.H. Blackburn, and L.B. Merrill. 1984b. Effects of livestock grazing on sediment production, Edwards Plateau of Texas. J. Range Manage. 37:291-294.

McGinty, W.A., F.E. Smeins, and L.B. Merrill. 1979. Influence of soil, vegetation and grazing management on infiltration rate and sediment production of Edwards Plateau rangeland. J. Range Manage. 32:33-37.

McMillan, W.D., and R.H. Burgy. 1960. Interception loss from grass. J. Geophys. Res. 65:2389-2394.

Ndawula-Senyimba, M.S., V.C. Brink, and A. McLean. 1971. Moisture interception as a factor in the competitive ability of bluebunch wheatgrass. J. Range Manage. 24:198-200.

Nelson, D.W., and L.E. Sommers. 1982. Total carbon, organic carbon, and organic matter, p. 539-579. In: A.L. Page (ed), Methods of Soil Analysis, Part 2. Amer. Soc. Agron., Madison, Wis.

Osborn, B. 1954. Soil splash by raindrop impact on bare soils. J. Soil and Water Conserv. 9:33-49.

Pearson, G.A., G.A. Jung, R.E. Fowler, and D.M. Mitchell. 1975. Effects of grazing on infiltration rates and waste water spray fields. Proc. Soil Sci. Soc. Amer. 29:954-957.

Pluhar, J.J. 1984. Hydrologic impacts of selected grazing systems on the Texas Rolling Plains. M.S. Thesis, Texas A\&M Univ., College Station.

Quinn, J.A., and D.E. Hervey. 1970. Trampling losses and travel by cattle on sandhills range. J. Range Manage. 23:50-55.

Roundy, B.A., J.A. Young, G.J. Cluff, and R.A. Evans. 1983. Measurement of soil water on rangelands. USDA Agr. Res. Service, Agr. Res. Results, Western Ser. 31.

Savory, A. 1978. A holistic approach to ranch management using short duration grazing, p. 555-557. In: First Internat. Range Congr. Soc. Range Manage., Denver, Colo.

Savory, A., and S.D. Parsons. 1980. The Savory grazing method. Rangelands 2:234-237.

Skovlin, J.M., R.W. Harris, G.S. Strickler, and G.A. Garrison. 1976. Effects of cattle grazing methods on ponderosa pine-bunchgrass range in the Pacific Northwest. USDA Forest Service Tech. Bull. 1531.

Smith, R.P. 1980. The influence of different grazing practices on infiltration rates and sediment production at Fort Stanton, New Mexico. M.S. Thesis, New Mexico State Univ., Las Cruces.

Snedecor, G.W., and W.C. Cochran. 1971. Statistical methods. Iowa State Univ. Press, Ames, Ia.

Steel, R.G.D., and J.H. Torrie. 1980. Principles and procedures of statistics. McGraw-Hill Book Co., New York.

Stoddard, L.A., A.D. Smith, and T.W. Box. 1975. Range management McGraw-Hill Book Co., New York.

Thurow, T.L. 1985. Hydrologic interrelationships with vegetation and soil as affected by selected livestock grazing systems and climate on the Edwards Plateau. Ph.D. Diss., Texas A\&M Univ., College Station.

Van Haveren, B.P. 1983. Soil bulk density as influenced by grazing intensity and soil type on a shortgrass prairie site. J. Range Manage. 36:586-588

Voisin, A. 1959. Grass productivity. Philosophical Library, Inc., New York.

Warren, S.D., W.H. Blackburn, and C.A. Taylor, Jr. 1986a. Soil hydrologic response to number of pastures and stocking density under intensive rotation grazing. J. Range Manage. 39: (In press).

Warren, S.D., M.B. Nevill, W.H. Blackburn, and N.E. Garza. 1986b. Soil response to trampling under intensive rotation grazing. Soil Sci. Soc. Amer. J. 39: (In press).

Warren, S.D., T.L. Thurow, W.H. Blackburn, and N.E. Garza. 1986c. The influence of livestock trampling under short-duration grazing on soil hydrologic characteristics. J. Range Manage. 39:491-495. 
Weltz, M. 1983. The influence of short duration and continuous grazing on infiltration rate and sediment yield in southcentral New Mexico. M.S. Thesis, New Mexico State Univ., Las Cruces.

Willatt, S.T., and D.M. Pullar. 1983. Changes in soil physical properties under grazed pastures. Aust. J. Soil Res. 22:343-348.

Witschi, P.A., and D.L. Michalk. 1979. The effect of sheep treading and grazing on pasture and soil characteristics of irrigated annual pastures. Aust. J. Agr. Res. 30:741-750.

Wood, M.K. 1980. Impacts of grazing systems on watershed values, p. 163-170. In: K.C. McDaniel and C. Allison (eds), Grazing Management Systems for Southwest Rangelands. New Mexico State Univ., Las Cruces.
Wood, M.K., and W.H. Blackburn. 1981a. Grazing systems: Their influence on infiltration rates in the Rolling Plains of Texas. J. Range Manage. 34:331-335.

Wood, M.K., and W.H. Blackburn. 1981b. Sediment production as influenced by livestock grazing in the Texas Rolling Plains. J. Range Manage. 34:228-231.

Wood, M.K., and W.H. Blackburn. 1984. Vegetation and soil responses to cattle grazing systems in the Texas Rolling Plains. J. Range Manage. 37:303-308.

Wood, M.K., W.H. Blackburn, F.E. Smeins, and W.A. McGinty. 1978. Hydrologic impacts of grazing systems, p. 288-291. In: Proceedings of the First Internat. Range Congr. Soc. Range Manage., Denver, Colo. 